populations with a normal diapause-pattern showed a high susceptibility to organophosphorus compounds.

Fig. 1 shows the difference in diapause-pattern between a susceptible and an organophosphorusresistant population. At $20^{\circ}$ C. a régime of short photoperiods evoked only a small percentage of diapause forms in the resistant population. At $15^{\circ} \mathrm{C}$. resistant mites entered into diapause, but the percentage of diapause forms was significantly lower with the resistant population than with the susceptible one.

\section{W. Helie}

Experimental Station for Floriculture, Aalsmeer,

The Netherlands.

' Lees, A. D., Ann. App. Biol., 40, 449 (1953).

\section{Effect of Copper Deficiency in White Clover on Nitrogen Fixation}

IN view of a recent report by Hallsworth et al. ${ }^{1}$ that copper stimulates nitrogen fixation by subterranean clover (Trifolium subterraneum), the following evidence from a field trial is presented as indicating a similar function of copper in nitrogen fixation by white clover ( $T$. repens).

White clover was dissected from mixed herbage samples taken on November 27,1956 , from a rates of copper trial conducted by one of us (F. H. v. d. E.) on a pasture recently established on raw peat on the Moanatuatua swamp. The samples were analysed for copper and total nitrogen contents.

Many clover plants in the control plots showed characteristic copper deficiency symptoms-die-back with bleaching of the margins and rolling and collapse of the leaflets. The samples analysed were apparently healthy whole leaves (leaflets plus petioles).

Table 1. YraLds of Mixed Gerbage and Copper- and NitrogenLEVELS IN WHITE CLOVER

\begin{tabular}{|c|c|c|c|}
\hline Treatment & $\begin{array}{c}\text { Dry matter yield } \\
\text { (1b. per acre) } \\
\text { (\$pring 1956) }\end{array}$ & $\begin{array}{l}\text { Copper } \\
\text { (p.p.m. in dry } \\
\text { matter) }\end{array}$ & $\begin{array}{l}\text { Nitrogen } \\
\text { (percentage in } \\
\text { dry matter) }\end{array}$ \\
\hline $\begin{array}{l}\text { ntrol } \\
\text { lb. Bluestone } \\
\text { lb. Bluestone } \\
\text { lb. Bluestone } \\
\text { lb. Bluestone } \\
\text { lb. Bluestone } \\
\text { gnifieant } 5 \% \\
\text { lifferences } \quad 1 \%\end{array}$ & $\begin{array}{r}2,090 \\
3,330 \\
3,410 \\
3,540 \\
3,520 \\
3,520 \\
350 \\
470\end{array}$ & $\begin{array}{l}2 \cdot 5 \\
3 \cdot 6 \\
4 \cdot 0 \\
6 \cdot 6 \\
7.2 \\
8 \cdot 2 \\
0.78 \\
1.05\end{array}$ & $\begin{array}{l}4 \cdot 25 \\
4 \cdot 88 \\
4 \cdot 94 \\
5 \cdot 05 \\
5 \cdot 00 \\
5 \cdot 03 \\
0 \cdot 16 \\
0.21\end{array}$ \\
\hline
\end{tabular}

The copper treatments resulted not only in increased growth of white clover and elimination of deficiency symptoms, but also in significantly higher concentrations of total nitrogen. Incubation tests of the peat soil with copper additions failed to demonstrate any increase in mineral nitrogen-levels. The clover nitrogen-levels in the controls were relatively low for succulent spring growth under local conditions, but normal in the copper-treated plants. The presence of copper deficiency symptoms together with low nitrogen- and very low copper-levels suggests that the increases in nitrogen concentrations in the clovers were due to a specific effect of copper on nitrogen fixation by white clover.

\section{F. H. VAN DER ELST \\ K. J. MoNaUght \\ W. F. RoLt}

Rukuhia Soil Research Station,

Hamilton, New Zealand.

'Hallsworth, E. G., Wilson, S. B., and Greenwood, B. A. N., Nature,

\section{Limitations of the Periodic Acid-Schiff Technique for the Demonstration of Stages of Eimeria in Tissues}

Is a recent communication, Jennings ${ }^{1}$ suggested that the periodic acid-Schiff technique is useful for the demonstration of all stages in the life-cycles of four species of eoccidia occurring in the intestine of the fowl. These species were Eimeria acervulina, $E$. maxima, $E$. necatrix and $E$. tenella.

The periodic acid-Schiff technique was first applied to Eimeria by Lillie $^{2}$, who obtained positive reactions in the cytoplasm of oocysts of $E$. stiedae from the rabbit. More recently, this technique was used by Cheissin ${ }^{3}$ on $E$. magna, $E$. media and $E$. intestinalis from the rabbit, Pattillo and Becker ${ }^{4}$ on $E$. acervulina and $E$. brunetti from fowls, Gill and Ray $^{5}$ and Tsumoda and Itikawa ${ }^{6}$ on $E$. tenella from fowls. These authors all failed to obtain positive reactions by the periodic acid-Schiff technique with some stages of these life-cycles. Cheissin found that isolated microgametes were negative and that microgametocytes gave only an insignificant reaction. Pattillo and Becker obtained no positive reactions using the Hotchkiss ${ }^{7}$ periodic acid-Schiff technique with the microgametocytes and schizonts of both $E$. acervulina and $E$. brunetti, although the merozoites of $E$. acervulina gave a weak reaction. Developing macrogametocytes were often negative.
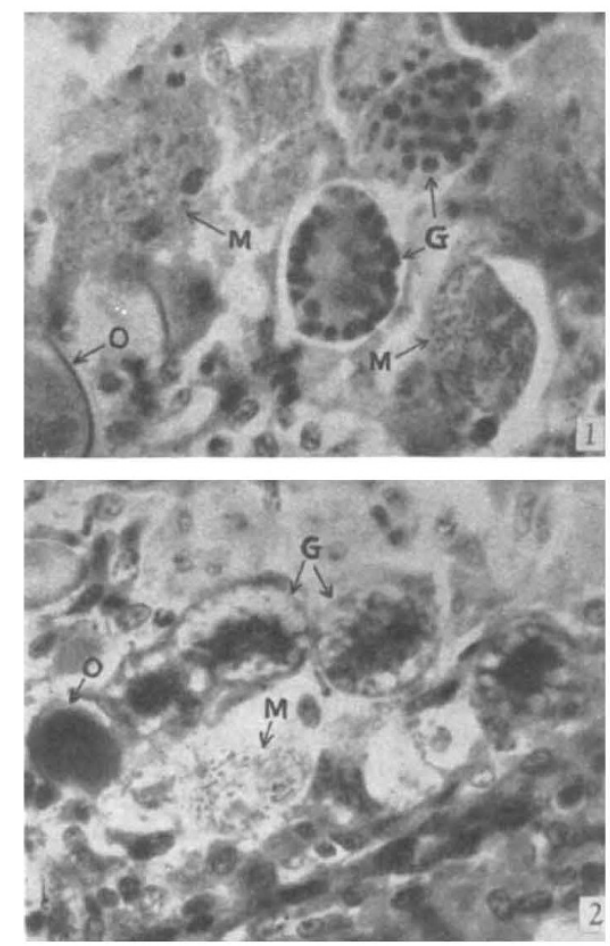

Fig. 1. Section of small intestine infected with $E_{.}$maxima and flxed in formol saline; stained by Hotchkiss periodic acid-Schif technique and counter-stained with hæmalum. Note the intens staining of the 'plastic granules' $(G)$ in the macrogametes and oocyst wail $(O)$. The microgameth the hroctum but not with the periodic acidSchiff reagent. $(\times 525)$

Fig. 2. Section of small intestine infected with $\boldsymbol{E}$. maxima and fixed with Bouin's fluid; stained by Hotchkiss periodic acid Schiff technique and counter-stained with hæmalum. Note the lack of preservation of the plastic granules in the macrogametes $(G)$; the microgametocytes and microgametes $(M)$ have stained with the hæmalum, but not with the periodic acid-Schiff reagent. $(\times 525)$ 